\title{
Scientific Exegesis of Al-Quran and Its Relevance in Dealing with Contemporary Issues: An Appraisal on the Book of 'Al-Jawahir Fi Tafsir Al-Quran Al-Karim
}

\author{
Lukman Abdul Mutalib, Wan Abdul Fattah Wan Ismail, Ahmad Syukran Baharuddin, Mohd \\ Faisal Mohamed, Abd Hamid Abd Murad, Kamarul Arifin Wafa
}

\begin{abstract}
Al-Quran, as the last Holy Book sent down by Allah, is remarkably different from its predecessors. Ultimately, it has to be the only one of such a kind. More so since the universal nature of the divine guidance it carries within is valid and relevant for all of humanity of all ages, spaces and times. True to its character as an enduring miracle, science can never dismiss the truth of Al-Quran as it accordingly, can be scientifically proven, time and again, without fail. Sheikh Tantawy Jauhary, among others, is one of those renowned scholars of Tafsir (exegesis) who studied the scientific attributes of Al-Quran. Sheikh Tantawy's seminal work, "Al-Jawahir Fi Tafsir al-Quran al-Karim", applied scientific methods of exegesis via his observation of the spectacular creation of the universe as a hard and living evidence of the all-powerfulness of Allah. For centuries, Muslims depend on Al-Quran, through its Kawniyyah verses, to study the universe. It needs to be highlighted that there are about 750 verses of Kawniyyah in Quran as opposed to only 150 verses of Fiqh (Jurisprudence). Besides, apart from providing scientific exegesis of Kawniyyah verses, Sheikh Tantawy also deliberated on verses over laws and morality as well the uniqueness of the creatures like the animals, plants, heavens and the earth. Accordingly, this paper provides a succinct overview of the bibliography of Sheikh Al-Tantawy and his thoughts in the exegesis of Al-Quran. By highlighting a number of relevant examples of Sheikh Al-Tantawy's scientific exegesis, it consequently provides an analysis of the significance and essentiality of the need and necessity of such a method of Tafsir in order to deal with contemporary issues.
\end{abstract}

Keywords: DNA, finger print, law of evidence, scientific proofing, scientific tafsir, Sheikh Tantawy Jawhary.

\section{INTRODUCTION}

Kamus Dewan (Dewan Dictionary) defines "Tafsir" as the explanation or clarification. Literally, it means explanation or

Revised Version Manuscript Received on September 16, 2019. Judiciary, Islamic Science Institute (ISI), Faculty of Syariah and Law, Universiti Sains Islam Malaysia (USIM), Nilai, Negeri Sembilan, Malaysia.

Wan Abdul Fattah Wan Ismail, Centre of Research for Fiqh Forensics and Judiciary, Islamic Science Institute (ISI), Faculty of Syariah and Law, Universiti Sains Islam Malaysia (USIM), Nilai, Negeri Sembilan, Malaysia.

Ahmad Syukran Baharuddin, Centre of Research for Fiqh Forensics and Judiciary, Islamic Science Institute (ISI), Faculty of Syariah and Law, Universiti Sains Islam Malaysia (USIM), Nilai, Negeri Sembilan, Malaysia.

Mohd Faisal Mohamed, Faculty of Syariah and Law, Universiti Sains Islam Malaysia, Nilai, Negeri Sembilan, Malaysia.

Abd Hamid Abd Murad, Faculty of Syariah and Law, Universiti Sains Islam Malaysia, Nilai, Negeri Sembilan, Malaysia. Negeri Sembilan, Malaysia.
Lukman Abdul Mutalib, Centre of Research for Fiqh Forensics and

Kamarul Arifin Wafa, Kamarul Arifin Wafa \& Associates. Seremban,

clarification of the verses in Al-Quran [1]. In this context,"Tafsir" is understood as "takwil" that provides similar meaning. However, in the academic world, both "Tafsir" and "takwil" connote different meanings. On a closer look of the Quranic verses, we will find that "Tafsir" revolves more on and around the activity of narration such as interpreting Quranic verses based on the Prophet's "hadith" (Prophetic traditions) or the opinions of the Prophet's companions. Takwil, on the other hand, refers to the activity of "Taakkul" (exhaustive reasoning) of a particular Quranic verse. Hence, the Prophet's "du'a" (pray) for Ibn Abbas in which he says "O Allah! Make him (Ibn `Abbas) a learned scholar in religion (Islam) [2]. Nevertheless, it is not uncommon for the society to understand both "Tafsir" and "takwil" as synonymous.

\section{HISTORY OF THE WRITING OF TAFSIR}

The writing of Tafsir has gone through several eras. Some scholars have divided the history of Tafsir into three: Pre-Publication, Publication and Modern eras.

The pre-publication era refers to the times of the Prophet (pbuh), the companions and the "Tabi'ien". Among the distinguished attributes of "Tafsir" during this phase is its simplicity and clarity. It can generalized that topics of "Tafsir", at this time, center more on issues of the nature of "al-'am" and "khas", "mutlaq", "muqayyad", "mujmal" and "mubayyan". Furthermore, the sources to interpret Al-Quran include those Quranic verses that explain one another, Prophetic traditions (Hadith), "asbab al-nuzul" and the contemporary authentic establishment of Arabic language.

On one hand, the following is one example of Quranic interpretation based on another Quranic verse: "Then Adam received from his Lord [some] words, and He accepted his repentance". (Al-Baqarah, 2:37) - which is interpreted by another verse: They said, "Our Lord, we have wronged ourselves, and if You do not forgive us and have mercy upon us, we will surely be among the losers." (Al-A'raf: 23). On the other, what follows is an example of a Quranic interpretation based on a Hadith: "And those who hoard gold and silver" (Al-Taubah 9:34).

Ibn Abbas narrates that when the above verse was

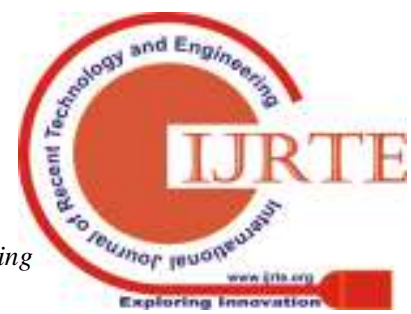


revealed, the companions were feeling uncomfortable over of the prohibition concerning wealth accumulation. Thus, Saidina Umar asked the Prophet (pbuh):

O Prophet of Allah, indeed this verse has put your companions at unease. The Prophet replies: "Verily, Allah does not oblige you with zakat except for what you find as surplus and that Allah has made farai'd (law on inheritance) compulsory so that your property stays with those whom you leave behind when you die (offsprings). Immediately, Saidina Umar exclaimed takbir (out of sheer relief upon

Furthermore, in this hadith, the Prophet clarifies that the verse "And those who hoard gold and silver" refers to those refusing to issue zakat [4].

Interpreting Al-Quran based on "Israiliyyat" method was unheard of during the time of the Prophet (pbuh) and the companions. This method only made its first appearance in the time of the Tabi'ien. Ibn Abbas narrates:

"O the people of Islam! Why would you counsel the people of the books (Bible and Torah)? Here is your holy book, revealed unto His Prophet Muhammad (pbuh) which carries with it the latest news from Allah, and this you must read (Al-Quran) for it comes pristine, pure and uncorrupted with any other previous books. Allah has told you that the people of the books have altered what have been revealed to them, they amended them with their hands and yet they claimed, these are from Allah. They sell the words of Allah with a very cheap price. Would you not take these as Allah's prohibition against you counselling the people of the books on matters of your religion? In the name of Allah, never did I see any of the people of the books come and ask of what has been revealed to you [5]". Muslim territories expanding vastly, differences of opinions were rife, a multitude of new "Mazhab" (sects) appeared and a number of new schools of thoughts were gaining global recognition, both on the fields of aqidah and fiqh. Among the well-known experts of Tafsir during this era were Mujahid, 'Atha' bin Abi Rabah and Ikrimah from Ibn Abbas's madrasah (Ahlu Makkah). Additionally, Zaid bin Aslam, Abdul Rahman as well as Abdullah bin Wahab were famous experts of Tafsir who hailed from Ibn Mas'ud's madrasah (Ahlu Kufah). At the same time, reference to Israillliyyat was already viral. One of the contributing factors was the prevalence of narration activity without "Sanad" in which the question of the source authenticity was no longer a top priority as it was during the era of the companions.

In general, Tafsir activity during the pre-publication era appears to be a clear-cut and straightforward business. The Prophet (pbuh) interpreted the Quranic verses for his companions and they never asked for the interpretation of the Mutasyabih verses. Even so, clashes of opinions among the companions were rare. For Tafsir, they relied only on Al-Quran, Hadith, the other companions' narrations and the authentic Arabic language specialists. Additionally, the companions never applied Israillliyyat in interpreting Quranic verses. In the era of the Tabi'ien, these were no longer necessarily the case mostly due the dawn of a new era and the expanding demography of the people. This was the time when some of the Tafsir experts began to apply Israillliyyat. Nevertheless, it must be stressed herewith that it hearing the Prophet's answer) [3].

The era of Tabi'ien saw a host of new changes. With the

was only limited to secondary issues whether or not they existed or otherwise and that it did not involve the basic issues or the 'factual issue' [4]. A good way to illustrate the key difference between the two is through the story of Prophet Yusuf (pbuh). The 'brother of Prophet Yusuf' and the 'wife of al-Aziz' are the factual issues. Their names, Bunyamin and Zulaikha, are the secondary ones.

The second stage is the publication era. It is difficult to ascertain the exact date when this era began in its earnest. However, in the second century of Hijrah calendar year, Tafsir publication was extensive and common. Among the famous Tafsir experts during this era are Ibn Jarir al-Tabary, al-Jassas, al-Qurtuby, al-Alusy, al-Sayuty and many others [6]. At the same time, several new institutions of educations were established. They include Madrasah al-Bayaniyyah through the writing of Ibn Qutaybah of "Ta'wil Musykil Al-Quran", Madrasah al-Fiqhiyyah through the writing of Imam al-Qurtuby of "Al-Jami' Li Ahkam Al-Quran", Madrasah al-'Aqadiyyah through the writing of Imam Fakhruddin al-Razy of "Mafaatih al-Ghaib", Madrasah Tafsir bi al-Ma'thur through the writing of Imam Ibn Kathir of "Tafsir Ibn Kathir", Madrasah al-Mutasawwifah through the writing of Imam al-Qusyairy of "Lata'if al-Isyarat", and Madrasah al-Wa'ziyyah through the writing of Imam al-Khatib al-Syarbini of "Tafsir al-Khazin".

The third stage i.e. towards the end of the 19th century until now is taken to be the era of the modern Tafsir. Books on Tafsir written and published in this era bore their own signature writing styles which are obviously different from the previous eras. They contain the influencing effects of the surrounding environment, the developing and growing of the body of knowledge as well as the authors' own predispositions. These works on Tafsir that come with much simpler features are contemporary in nature and easier to understand. They are also very clear in their rejection of taqlid and as a result, encourage and welcome, the process of ijtihad. As such, a larger part of the contents of the Tafsir produced focus on the societal issues, politics, spreading out of new and modern knowledge as well as religious, intellectual discourses on aqidah and fiqah issues. In this era, significantly new ways to write Tafsir made their debut. They are:

- Ittijah al-Bayany: Tafsir based on Arabic linguistics.

- Ittijah al-Fiqhy: Tafsir with a focus on laws of fiqh.

- Ittijah al-'Aqady: Tafsir with a focus on aqidah issues.

- Ittijah al-'Ilmy: Tafsir that links scientific research with Al-Quran.

- Ittijah al-Mawdhu'ie: Tafsir based on particular topics and others.

Prominent Tafsir experts of this era include, inter alia, Sheikh Mustafa al-Maraghi of "Tafsir al-Maraghi", Sayyid Qutb of "Fi Zilal al-Al-Quran" and Sheikh Tantawy Jauhary of "Tafsir al-Jawahir Fi Tafsir al-Quran", which, is the focus of this paper.

The paper provides a brief analysis of Tafsir writing by Sheikh Tantawy Jauhari through his signature work, "Tafsir al-Jawahir Fi Tafsir al-Quran". Generally, this Tafsir is 
categorized under Ittijah al-'Ilmy i.e. Tafsir that ties the understanding of Quranic verses with that of the new modern knowledge.

\section{BIBLIOGRAPHY OF SHEIKH JAUHARY TANTAWY}

Sheikh Jauhary Tantawy was born in 1862 to a family of a farmer in the village of "Kufr 'Iwadhullah Hijazi", a district of Zaqaziq, Egypt. He grew up memorizing Al-Quran at a Kuttab (school) near his family home. This is where his deep passion for knowledge began to grow in earnest. In 1877 , only at 15, he started his studies in Arabic language and the Fiqh of Syafi'e Sect at the University of Al-Azhar. But, after a few years, he got ill and because of his illness is severe, he had no choice but to return home. While recuperating, based on the old books of medicines he came across while in the University, Sheikh Jauhary Tantawy prepared home-made medications both for himself and his father who was also ill at that time.

After a three year study break, Tantawy resumed his studies in Al-Azhar and became the student of Sheikh al-Bulaqy. His teacher realized Tantawy's deep interest in astronomy and let him borrow a book. Tantawy was so elated and wrote:

"When I was at al-Azhar, I was deeply fascinated by the moon and the stars. Every night, I looked up the sky and was amazed by its beauty. Yet, I felt so sad that I knew very little about it" [7].

Upon graduating from Al-Azhar in 1889, Tantawy joined Madrasah Darul Ulum until 1893. Here, Tantawy studied modern disciplines of knowledge of which Al-Azhar did not offer. Tantawy learned Mathematics, Engineering, Algebra of Astronomy (al-Jibra Falak), Chemistry and Botany. Tantawy also studied the Fiqh of Hanafi Sect from his teacher, Sheikh Hassunah al-Nawawy.

After finishing his study, Tantawy began to work. He taught at several schools in Buhairah and Gizah before rejoining Madrasah Darul Ulum in 1911. Soon he was appointed as one of the Academic Committee Members of University of al-Misriyyah al-Qadimah. Then, he was offered the post of Qadhi but kindly turned it down. Tantawy continued teaching until 1922. He authored many books that include:

• الزهرة في نظام العالم والأمم العز

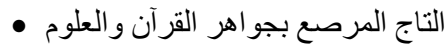

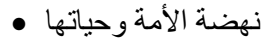

- النظام و الإسلام and others.

His masterpiece, "Al-Jawahir Fi Tafsir al-Al-Quran", contains 36 volumes. What makes this Tafsir exceptional and unique is that, it discusses Al-Quran through the perspective of modern theory and, accordingly, the introduction of new theories based on Quranic verses.

In 1940, Tantawy's works eventually received global attention and was fittingly awarded with the Nobel Laureate. He was the first Egyptian and the first Arab recipient for such a prestigious award. Tantawy died in the same year. Despite his short life, Tantawy has left behind a priceless legacy of knowledge for the Muslim world that continues to be well-regarded until today.

Tantawy’s “Al-Jawahir Fi Tafsir al-Al-Quran” drew many praises as well as critics. Some were hard on him while some others kept a very positive tone; and each opinion stands with their own reasons. The critics notwithstanding, Tantawy's way of Tafsir was extraordinarily unconventional of the existing style of writing Tafsir.

\section{IV. "AL-JAWAHIR FI TAFSIR AL-QURAN": A THOUGHT FROM THE FUTURE}

Sheikh Tantawy, through his "Al-Jawahir Fi Tafsir al-Al-Quran", deliberates on numerous scientific issues. Sheikh Tantawy combines and ties Quran with the results of scientific researches. Among the favorite topics that Sheikh Tantawy treats with his scientific approach are Astronomy, the creation of heaven and earth, human's life, animals, things (jamadat), discovery of modern knowledge from the perspectives of Mathematics, Physics, Biology, Chemistry and others. Tantawy also expands his scientific reasoning to include the conventional interpretation on the laws of Fiqh (jurisprudence), Akhlaq (moral) and Aqidah. The paper will discuss some the examples of the scientific Tafsir of the Al-Jawahir.

"Hadis al-Ifk" is one of the most interesting instances. A majority of Tafsir authors studying this issue approached it from the standpoints of historical and Fiqh laws. Tantawy's method was relatively different. Instead of doing away with the conventional method of Tafsir, Tantawy infused it with scientific elements, seen by many as a valuable and relevant addition to the modern life. Tantawy's might at first appeared to be bizarre and unusual in the eyes of the other Tafsir experts. But Tantawy's method soon received public approval along with the ascendancy of modern knowledge and cultural change.

The controversy over "Hadis al-Ifk" began when the Munafiq (Hypocrites) of Madinah accused Aisyah (r.a) of committing "Khalwat" (close proximity with a stranger of the opposite sex) with Safwan bin Mu'attal. It was rumoured to have occurred when the Muslim army was returning home from the battle against Bani Mustaliq. With the rumour becoming so widespread, Allah (s.w.t), in defense of Aisyah (r.a), reveals the following verses that warn against those attempting to smear the innocence of a woman with "Qazaf" accusation:

"Indeed, those who [falsely] accuse chaste, unaware and believing women are cursed in this world and the Hereafter; and they will have a great punishment. On a Day when their tongues, their hands and their feet will bear witness against them as to what they used to do". Surah A-Nur: 22-2

For Sheikh Tantawy, the meaning of the words "on the day their tongues and hands become the witness" should not necessarily be taken to refer only to the event on the judgement day whereby all of mankind will face the ultimate trial before Allah. Those verses, on the other hand, also speak about the life of men in this world. One's character and attitude can be adjudged from the way they act and behave. In other words, only a person with an evil heart will commit evil acts, conveyed through his/her hands and feet that are 
representative of a bad person.

Allah also says:

"Until, when they reach it, their hearing and their eyes and their skins will testify against them of what they used to do. And they will say to their skins, "Why have you testified against us?" They will say, "We were made to speak by Allah, who has made everything speak; and He created you the first time, and to Him you are returned". Surah 41: 20-21

Allah also says:

"That Day, We will seal over their mouths, and their hands will speak to Us, and their feet will testify about what they used to earn". Surah Yaasin: 65

These verses, Sheikh Tantawy added, are stating the obvious. The hands, feet, skin and the eyes are our witnesses in this world. So, when Allah (s.w.t) states that the hands, feet, skin and the eyes will become the witness for Allah on judgement day, why would you not use them as your witnesses on this world as well? Does it not Allah (s.w.t) bear witness with these matters? Therefore, it is only all the more appropriate that you make use of them.

Human body has so many secrets. The hands, feet, skin and eyes are full of secrets of which discovery were made only in recent times. For example, there is no similar or identical fingerprint. The feet, likewise (al-Qifayah). The eyes are capable of sending out signs of whether one is telling the truth or otherwise. They can even provide indications of one's health. Moreover, the skin also plays a key role in the state-of-the-art research of DNA. As a matter of fact, all parts of the human body are telling their stories. They are talking about what they have done.

An Arab poet says:

"Indeed, the words are borne out of the heart, and surely the tongue is no more made to be nothing more than just as the emissary of the heart" [8].

Referring to the same context, Allah says:

"And in yourselves. Then will you not see (signs and proofs)?" Surah Al-Zhariyyat: 21

Furthermore, Allah says

"(It will be said), "Read your record. Sufficient is yourself against you this Day as accountant (about everything that you did)". Surah Al-Isra: 41

The fact that matters is that apparently, the verses above, have paved the way for the scientific interpretation of Al-Quran. They even serve as a testimony of the miracle of Al-Quran seen from the point of view of knowledge. Still, this is only one of the many other examples in the "al-Jawahir".

\section{SCIENTIFIC TAFSIR AND ITS RELEVANCE IN DEALING WITH CONTEMPORARY ISSUES \& RESULTS}

Ittijah al-'ilmy as a method in interpreting Al-Quran as mentioned previously had only appeared in the recent time. It was borne out of the pressing need of the society to embrace the arrival of a new civilization and new disciplines of knowledge. Accordingly, as long as it is deemed to have not violated the general rules of Tafsir as laid out by the U'lama, this method is considered to be generally relevant, and therefore, accepted.

In considering its relevance, the paper seeks to make an example of a tool of proof accepted in the Islamic law of evidence, otherwise known as "Dalil al-ithbat". Scientific evidence is widely accepted these days. From the viewpoint of the Islamic law of evidence, scientific evidence falls into the category of Qarinah. It is considered as the circumstantial evidence. According to Adnan Hasan Azyizah, Qarinah is defined as كل أمر ظاهر يصاحب شبئا خفيا فيذل علبه (everything visible that proves with it the presence/being of the invisible) [9]. According to Kelantan Evidence Enactment of the Syariah Court 1991, Qarinah is defined as "A fact connected with the other in any of the ways referred to in Hukum Syarak or the provisions of this Enactment" [10].

Qarinah has three forms.

\section{Qarinah qati'ah - (Strong and certain)}

It is defined as a proof with a maximum level of certainty. For example, a free woman who gets pregnant out of wedlock without any admissible defence (to deny the possibility of zina) is a strong type of Qarinah, beyond reasonable doubt, that zina has definitely occurred [11], [12].

Some contemporary religious scholars have also classified fingerprint evidentiality as a very strong Qarinah that attains a maximum level of certainty, with blood and urine testing can also prove, beyond any doubt, whether a person has or has not consumed intoxicating substance. According to Anwar Mahmud Dabbur Blood test only shows whether a person has or has not consumed an intoxicating food or beverage. Nevertheless, the test result is not sufficient to convict the person under hudud because the conviction requires support from other type of evidence which is capable of proving that the person's act is intentional beyond doubt [13].

Scholars consider such a level of maximum certainty mentioned above as "źan al-ghālib". Reason being there is absolutely no way of attaining more than a maximum level of certainty and as such, all the conviction methods available regardless of how convincing they are - will not outdo that of źan al-ghālib [14], [9], [15]. Discourses by Fuqaha Jurists on Qarīnah give strong emphasis on this type of Qarīnah.

\section{Qarinah d'a'ifah (weak)}

It is a kind of an uncertain proof that comes with several assumptions which are unable to prove or deny those assumptions. It cannot be accepted as evidence but can function as a Tarjih (support/inclined towards an opinion) of a matter.

For example, a dispute between a married couple over the ownership of properties with both unable to offer irrefutable evidence of clear-cut ownership. In this case, based on this type of Qarinah, scholars argue that those commonly used by the husband belong to him and vice versa [16].

\section{Qarinah batilah (false/null)}

It is a kind of evidence of no strength - simply a mere suspicion or an uninformed assumption. Occassionally, it may come with a basis but it contradicts a stronger Qarinah which efectively renders it as void.

For example, the brothers of Prophet Yusuf (pbuh) claimed that Prophet Yusuf was killed by the wolf. The former offered a few Qarinah proofs such as the latter's cry, 

contradicted a stronger Qarinah i.e. Prophet Yusuf's fine and tornless shirt. Had Prophet Yusuf been attacked by the wolf, his shirt must have been severely torn apart. Such is a type Qarīnah al-bāţilah and Syarak has no option but to dismiss it completely.

The admissibility of evidence through scientific method has been discussed before. As such, the paper offers another Quranic verse as evidence.

Allah says:

"Does man think that We will not assemble his bones? Yes. [We are] Able [even] to proportion his fingertips".

\section{Surah Al-Qiyamah 75: 3-4}

These verses explain Allah's supreme power to reassemble perfectly men's totally disintegrated fingers and bones. If these verses are literally taken, only to refer to the state of affairs on the day of resurrection of the hereafter, then it comes as a very easy thing for Allah to do. Allah creates men out of nothing. Repeating it, then, is absolutely effortless. The truth is, the significance of these verses lies in the fact that Allah is reiterating the fact that whatever is left of the completely disintegrated bones can be brought back to perfection - back to life in this world - with such a divine ease. In other words, the bones can reveal their identities just as much as a living man can of himself.

This interpretation suits another verse in which Allah says:

"That Day shall We set a seal on their mouths. But their hands will speak to us, and their feet bear witness, to all that they did". Surah Yaasin: 65

According to Syeikh Tantawy, the hands and the feet can tell what they have done despite the mouth denying them. Not only this is possible in the hereafter, but also in this world. As a matter of fact, this is the role of DNA, fingerprint and others [17].

Ultimately, scientific evidence can be accepted as a tool of proof in a trial of a court of law. Nevertheless, it must be endorsed and authenticated by the experts beforehand. These experts are contemporarily known as the forensic experts. An expert's testimony can be accepted so as to determine the existence of a circumstance. Additionally, they can be categorized as ahlu al-Zikr.

In this context, Allah says:

"And We sent not before you, [O Muhammad], except men to whom We revealed [the message], so ask the people of the message if you do not know". Surah Al-Anbiyaa: 7

One of the greatest scientific breakthroughs of the recent time is the discovery of DNA (Deoxyribonucleic Acid). DNA is a molecule ( $\mathrm{s}$ ) that stores genetic codes which determine a person's unique features such as colors of the eyes and skin as well the types of hair and others. The discovery of the method to establish one's identity was made by Sir Dr Alec Jeffreys of Leicester University, England in 1984 [18]. These days, the use of DNA has played a key role in solving numerous cases, especially those of crimes. The presence of DNA, or its absence, can help establish one's conviction of a crime or otherwise. Apart from using DNA in criminal cases, it is also used in establishing one's line of ancestry.

The use of DNA is also substantiated by a Hadith of the Prohet Muhammad (pbuh). The case of Hilal Ibn Umayyah provides a good illustration of this. Hila's wife was accused of committing zina (adultery) with Syuraik Ibn Sahma'. It sadness and blood stains on the latter's shirt. However, these

was so serious that li'an procedure had to be commenced. During the process, Hilal first made his solemn statement (accusing his wife of zina) for five times. His wife then did the same (denying the accusation) in the exact numbers. However, at the fifth, Hilal's wife suddenly stuttered. She was finding it difficult to finish her fifth solemn statement that the companions were beginning to think that Hilal's wife would soon retract her statement. But she persevered and stated, "I will not put a shame on my people". She proceeded and completed her fifth solemn statement.

Looking at this, the Prophet says:

"See (the child of) this woman, should she give birth to a child whose eyes are black in color, with lean buttocks and a round leg (stocky), then the child belongs to Syuraik b Sahma' (child out of wedlock)". Not long after, the child was born with the exact features as was pointed out by the Prophet. Then the Prophet says: "If not for the verse (on li'an), I would still have unfinished business with her" [19].

This Hadith stresses the permissibility of relying on biological traits as a form of evidence (Qarinah). Putting it differently, had it not been due to the verses on li'an, just merely upon the confirmed presence of the biological traits, the Prophet (pbuh) would have put Hilal's wife to stoning to death as a punishment for zina as provided for under Syariah laws. Those traits, as the Prophet (pbuh) has underscored in the Hadith, as well in other Qifayah Hadith, are the external physical features of an individual, for which DNA is also responsible, in addition to a person's distinctive internal features like blood type.

Besides, obtaining similar DNA results of two closely related individuals is extremely difficult, if not impossible. For the DNAs of two closely related individuals to be considered identical, they have to be achieve a $99.9 \%$ accuracy. What does this mean? It means there can be only a $0.1 \%$ difference before the data can be considered as admissible in a court of law to prove an individual's relation with the other. As such, a DNA proof must achieve an accuracy level of $99.9 \%$, for which hitherto, there is no other form of evidence that can outdo the reliability of DNA.

The DNA authentication process is carried out by forensic experts who will run a test on samples acquired either from the scene of crime or the next of kin in a dispute over nasab (descendancy). The testimony of a forensic expert is accepted in Syariah court via Section 33(1) Syariah Court Evidence (State of Selangor) Enactment 2003 which states, "When the Court has to form an opinion upon a point of foreign law or of science or art, or as to identity or genuineness of handwriting or finger impressions or relating to determination of nasab, the opinions upon that point of persons specially skilled in that foreign law, science or art, or in questions as to identity or genuineness of handwriting or finger impressions or relating to determination of nasab, are Qarinah. Furthermore, Section 33 (2) of similar Enactment states, "Such persons are called experts" [20].

DNA is classified as Qarinah and the acceptance of Qarinah as evidence should be treated with care because accepting Qarinah as an admissible evidence is dissimilar 
with shahadah, iqrar and al-yamin. Despite the DNA being classified as Qarinah, the testimony of forensic experts, through DNA test, must be $99.9 \%$ accurate, which is so close to making it a $100 \%$ accuracy [21]. For some scholars, testimony of this means, can be used to convict a person with a crime of hudud and qisas as was shown by Saidina Umar, Saidina Ali and Saidina Uthman who accepted Qarinah as a proof of evidence of zina for women getting pregnant without husband and for those without slaves [22]. However, the basis of Qarinah is that it requires support or backing from other Qarinah in order to establish or rule out an existence of a circumstance.

\section{FINGERPRINTS}

A fingerprint is one of the most important Qarinah evidences in ascertaining the identity of an individual in both civil and criminal cases. Fingerprint serves as one of the conventional signatures along with stamps and hand-signature which are commonly used to validate transactions involving paper documents. Fingerprint can be defined as: "Putting the thumb on a stamp pad and transferring the thumb's ink stamp onto a document". As highlighted in the preceding pages, a fingerprint is the most critical characteristic and yet the simplest in differentiating and establishing an individual's identity over another. The argument is further proven by countless studies carried out by forensic experts that confirm beyond doubt the impossibility of two individuals bearing similar fingerprints. The unique shape of a fingerprint remains for life with an individual and will never change or become similar with others.

The basis for fingerprint identification is permanent and is unique for each individual. Theoretically, the larger parts of a fingerprint's features are determined by the surrounding conditions during the third to the fourth month of pregnancy and are permanently fixed thereafter for life. However, scars and warts are capable of altering a fingerprint a bit. Still, the popular belief is that, no two individuals, identical twins included, can ever have matching fingerprints. In 1892, Sir Francis Galton found that fingerprints could have from 35-50 identification features known as "Minutiae". The odd of two similar fingerprints is 1:64 billion.

Obviously, these scientific data show that modern scientific discoveries possess a remarkably high level of dependability. They are so strong that that they can even override and surpass the reliability of a witness and a confession. No matter of how reliable a witness is; he or she is still exposed to "Syahadah al-zurr". A threat of smear or slur might provoke one into confession, while one wishing to make an oath could be exposed to "Yamin al-ghamus". As such, there is no single tool of proof that could guarantee of $100 \%$ reliability. This, as a matter of fact, what Sheikh Tantawy had been wondering all along, that if Allah (s.w.t) would use these types of scientific evidences on judgement day, what then stops men from using them in this world?

Ibn Qayyim al-Jawziyyah makes it a point to emphasize the importance of Qarinah which includes the scientific evidences. Ibn Qayyim writes:

"This is a big issue; it (Qarinah) has huge benefits and commands exclusive attention (as evidence materials). The judges and the authority must never dismiss it. Otherwise, many truths will die away and as many falsehood will triumph".

\section{CONCLUSION}

In conclusion, scientific interpretation of Al-Quran is obviously a very important requirement for the contemporary society to deal with the contemporary issues. Not only does the linguistic miracle of Al-Quran is supreme and perfect, it also serves as a knowledge miracle that knows neither bound nor time-limit. There are plenty of modern discoveries that have confirmed the truth in Al-Quran, for which men of the ancient time had no way of finding out. The refusal to take a closer examination of Quranic verses in a scientific manner will only push Islam farther behind and could possibly make it void to the modern times.

\section{ACKNOWLEDGMENT}

This project was done under the Universiti Sains Islam Malaysia (USIM) Grant Scheme (PPPI/FSU/0217/051000/12718). Authors would to express their acknowledgment to the researchers from the Centre of Research for Fiqh Forensics and Judiciary (CFORSJ) Institut Sains Islam (USIM) for their cooperation.

\section{REFERENCES}

1. Dewan Bahasa dan Pustaka (DBP), Kamus Dewan. Kuala Lumpur: DBP, 2012.

2. Al-Hakim al-Naysabury, al-Mustadrak 'ala al-Sahihayn. Beirut: Dar al-Kutub al-'Ilmiyyah, 1990.

3. Al-Naisabury, Muhammad Abdullah, Mustadrak al-Hakim, Tahqiq Mustafa Abdul Qadir 'Ata. Beirut: Dar al-Kutub al-Ilmiyyah, 1990.

4. F. H. Abbas, al-Tafsir Asasiyatuhu wa al-Tujahatuhu. Amman: Maktabah Dandis, 2005.

5. Al-Bukhary, Muhammad Ismail, Sahih al-Bukhary. Bab La Yusalu ahlu al-Syirk 'An al-Syahadah.

6. Majlis Agama Islam Selangor, Perbendaharaan Al-Quran. Selangor: Pramaju Sdn. Bhd, 2008.

7. Ali al-Jumblaty, Fi Zikry Tantawy Jauhary.

8. Al-Jawjary Syamsuddin Muhammad Abd al-Mun'im, Syarh Syuzur al-Zahab Fi Ma'rifat Kalam al-Arab. Medinah: Universiti Islam Madinah, 2004.

9. A. H. Azayizah, Hujjiyat al-Qarain Fi al-Syari'ah al-Islamiyyah: DNA, Qiyafah, Petunjuk dan Darah. Amman: Dar Ammar, 1989.

10. Shariah Court Evidence 1991 Kelantan State.

11. Ibn Farhūn, Burhān al-Din Ibrahim Ali Abi al-Qāsim, Tabśirat al-hukkām fi usul al-Aqd'iah wa manāhij al-ahkām. Cairo: Maktabat al-Kulliyat al-Azhariyyah.

12. S. S. Jād, Ithbāt al-dawa al-jinā'iyyah bi al-qarā'in fi fiqh al-islāmī wa al-qanun al-wadī. Riyadh: Maţbaat Farazdak al-Tijāriah.

13. A. M. Dabbūr, al-Qarā'in wa dauruha fi al-ithbāt Fi Fiqh al-Jana'i al-Islamy. Cairo: Dar al-Thaqafah al-Arabiyyah.

14. A. I. Bak, Ţuruq al-ithbāt al-shariyyah maa bayān ikhtilāf al-mazāhib al-fiqhiyyah wa sharh al-adillat al-Muwāzanah bainaha thumma Muqāranat bi al-qānun wa mualliqan alaih bi Ahkām al-naqd'i. Cairo: Maţbaat al-Qāhirah al-Hadīthah.

15. A. M. Huuśary. Al-Qawāid al-kulliyyah li al-fiqh al-Islāmī. Cairo: Maktabat al-Kulliyat al-Azhariyyah.

16. Ibn al-Qayyim al-Jawzī, al-Țuruq al-ĥhukmiyyah. Beirut: 
Dar al-Fikr al-Lubnany.

17. T.. Jauharī, al-Jawāhir fi tafsīr al-Qurān al-Karīm. Cairo: Maţbaat al-Bābī al-Ĥalabī wa Awlāduh. 1351H.

18. Safa' Mahmood Muhammad al-'Ayasirah, al-Mustajiddat al-'Ilmiyyah Wa Atharuha 'Ala al-Fatwa al-Ahwal al-Syahsiyyah. Amman: 'Imaduddin Li al-Nasyr Wa al-Tawzi', 2009.

19. M. F. al-Humaydi, al-Jam' Bayn al-Sahihayn Bayn al-Bukhary wa Muslim. Beirut: Dar al-Nasyr, 2002.

20. S. S. Md Supi, Undang-undang keterangan Islam iktiraf ujian DNA. Available: http://www.ikim.gov.my/index.php/en/utusan-malaysia/7 594-undang-undang-keterangan-islam-iktiraf-ujian-dna.

21. S. S. Md Supi, Undang-undang keterangan Islam iktiraf ujian DNA. Available: http://www.ikim.gov.my/index.php/en/utusan-malaysia/7 594-undang-undang-keterangan-islam-iktiraf-ujian-dna.

22. Ibn Ĥjajar al-Asqalānī, Fath al-bārī. 